\title{
The influence of innovation and marketing strategy on the market-oriented activities of the company in cement industry: the decisive role of environmental dynamics
}

\author{
Sevda HOSSEINZADEH ${ }^{1}$, Reza ROSTAMZADEH ${ }^{2 *}$, Jonas $\check{S}^{\prime}$ PARAUSKAS $^{3}$ and \\ Violeta KER ŠULIEN $\dot{E}^{4}$
}

\begin{abstract}
Authors' affiliations and addresses:
${ }^{1}$ Department of Management, Khoy Branch,

Islamic Azad University, Khoy, Iran

e-mail: sevda.hz1989@gmail.com

${ }^{2}$ Department of Management, Urmia Branch,

Islamic Azad University, Urmia, Iran

e-mail: r.rostamzadeh@iaurmia.ac.ir
\end{abstract}

${ }^{3}$ Department of Construction Management and Real Estate, Faculty of Civil Engineering, Vilnius Gediminas Technical University, Lithuania

e-mail: jonas.saparauskas@vilniustech.lt

${ }^{4}$ Department of Law, Faculty of Business Management, Vilnius Gediminas Technical University, Lithuania

e-mail: violeta.kersuliene@ vilniustech.lt

*Correspondence:

Reza Rostamzadeh, Department of Management, Urmia Branch, Islamic Azad University, Urmia, Iran

e-mail: r.rostamzadeh@iaurmia.ac.ir

How to cite this article:

Hosseinzadeh, S, Rostamzadeh, R., Šaparauskas, J. and Kersuliene, V. (2021). The influence of innovation and marketing strategy on the marketoriented activities of the company: the decisive role of environmental dynamics. Acta

Montanistica Slovaca, Volume 26 (4), 748-760.

DOI:

https://doi.org/10.46544/AMS.v26i4.12

\begin{abstract}
To be more valuable to customers than competitors, a company must develop competitive business strategies through marketing and operations. The present study aimed to develop a model for evaluating the impact of innovation dimensions, marketing strategy and market orientation on the company performance with the moderating role of environmental dynamism. This research is descriptive-correlative and applied in nature. A questionnaire was used for data gathering. Two hundred ninety-one top managers from nineteen cement factories in Iran were selected as the sample. Structural equation modelling (SEM), specifically SMART PLS, has been employed to assess the causal model and verify the validity and reliability of the measurement model. The findings showed that innovation dimensions, market orientation, and marketing strategies had significant effects on the company's performance. Environmental dynamics modifies the relationship between process, product innovation, and performance, but process innovation is negative and significant. Finally, managerial implications and suggestions are provided. These findings provide valuable guidance for managers in the manufacturing sector to achieve the desired quality with the right strategies and create appropriate innovations in the manufacturing sector.
\end{abstract}

\section{Keywords}

Innovation, marketing strategy, market orientation, environmental dynamics, performance.

(C) 2021 by the authors. Submitted for possible open access publication under the terms and conditions of the Creative Commons Attribution (CC BY) license (http://creativecommons.org/licenses/by/4.0/). 


\section{Introduction}

Several types of research on innovation have aimed to understand how internal organisational factors such as technological capabilities, organisational culture, top management, human resources, and influence innovation. It is considered to be under the company's control, and managers can control or manipulate it to produce a particular result. On the other hand, there are only a few studies on the effects of external factors on innovation.

In order to support the implementation of strategy, companies design administrative systems based on the desired marketing strategy (MS) schemes. In increasingly turbulent business environments, companies have to change the desired and realised emerging strategies more often than in the previous era (Jintana \& Mori, 2019). Misalignments between strategies and existing administrative systems that support it may appear in the realised marketing strategies. MS and administrative system misalignments can be extracted both empirically and theoretically. Despite that, most MS studies have preferred empirical techniques over theoretically grounded approaches. Little emphasis has been placed on MS typologies and taxonomies, despite the commonality of the strategies classification at business levels in the marketing. Few studies have classified MS, have noticed marketing-related problems and applied them in empirical studies. Therefore, the conceptual prospect of MS is still immature (Chari et al., 2017).

As technology changes rapidly, the role of innovation in a company's survival has received a great deal of scholarly attention (Lee, Lee, \& Garrett, 2017). Generally, innovation is considered a vital component of the competitiveness of the processes and products of a company. Innovation is a continuous process (Naja et al., 2018).

Innovation studies have verified the effectiveness of innovation as a competitive strategy. It is because innovation may improve performance only in specific contexts. Consequently, managers should balance the company's innovation and environmental circumstances since the environment can moderate the relation between these two factors. Previous studies have shown the role of innovation in the two product and process innovations; thus, considering business contexts as the innovation predecessors. Marketing orientation (MO) increases businesses" financial and nonfinancial performances (D. Wang et al., 2019). MO is a fundamental concept in marketing publications, so there are comprehensive details of its impacts on innovation and performance. The potential source of such intelligence is marketing orientation, which the company mainly uses to scan and acquire market intelligence (Najafi-Tavani et al., 2016). The conceptualisation of MO has been done according to the two behavioural and cultural views.

Nevertheless, marketing orientation is the procedure of generating and disseminating market intelligence to create and offer better values to the customers. Thus, it has many advantages (Kirca et al., 2005; Najafi-Tavani et al., 2016). This study is different from past research. It considered the business environment as the moderating variable along with market strategy and market orientation, which can alter the impact of innovations on the performance of the businesses. However, from a strategic choice view, while we accept that the business environment can drive strategy, companies can choose their innovation and marketing strategies despite their business environment.

The study's structure is as follows. Section 1 reviews the published research, including competitive strategy, environmental dynamics (ED), market orientation (MO), and product/ process innovation. Section 2 presents research and hypothesis to develop models. Section 4 gives the research methodology. Section 5 provides the presented data analysis and discussion. Finally, Section 6 presents managerial implications and future studies.

\section{Theoretical Background}

Competitive strategies refer to the comparative positional supremacy of a company in the marketplace, which helps companies have good performance over their competitors (Porter, 1985). Previous publications have primarily concentrated on the differences and costs of strategies as competitive advantages. However, when a company operates with fewer costs than its competitors, it provides comparable products and can achieve a cost advantage (Liu \& Atuahene-gima, 2018). By distinguishing the product and its distribution and advertising, a distinction is made to competitive advantage, obtaining customer satisfaction and creating a strong brand. Increasing the market share results in the two competitive advantages for the company: (1) the cost of audit declines, and (2) services values offered to the clients enhance (İpek, 2021).

Unlike cost advantage, differentiation strategy not always increases market share (Taherdangkoo et al., 2019). Reinvestment to create a novel differentiation and, therefore, a continual competitive advantage becomes feasible when differentiation strategy becomes successful and highly profitable (Lee, Kim, Seo, \& Hight, 2015). Differentiation may be made in brand, product, technology and service. In general, cost leadership strategy positively affects the market share (Porter, 1980). According to the cost advantage, a company manufactures and vends more significant amounts than its competitors (Salunke et al., 2019). Therefore, it achieves higher profit which enhances its cost leadership. Porter (1980) distinguished three general strategies: differentiation, cost leadership, and focus. The purpose of the differentiation strategy is the creation of a product or service that customers regard as unique. Miller (1988) identified two different types of differentiation strategies: product 
innovation and those based on intensive marketing. The first strategy tries to produce the most up-to-date and exciting products by providing better qualities, efficiencies, designs innovation, and styles. The second strategy intends to provide a unique image of a product via marketing procedures. Differentiation through product innovation frequently includes novel technologies, unanticipated customers, competitors' reactions, and the confluence of several unstructured marketing problems.

Most of the literature on organisation and business policy theories have dealt with dynamism and suggested that turnover, lack of a pattern, and unpredictability were the most accepted measures of environmental instability (Ahmed \& Streimikiene, 2021). Environmental dynamism (ED) represents the speed of environmental modifications and instability levels. Dissimilarities in environmental features can result in more differences in the companies potential for acquiring sustainable competitive advantages (Liao, 2016). The environment has been an essential contingency in organisation theory and strategic management for many years. Numerous conceptualisations of the environment have been considered compatible with three dimensions of Dess and Beard (1984): munificence, complexity, and dynamism. Codifying environmental dimensions is indicated in a more parsimonious set in the following way (X. Wang \& Bao, 2017):

(1) Munificence: capacity;

(2) Dynamism: stability-instability, turbulence;

(3) Complexity: homogeneity-heterogeneity, concentration-dispersion.

These dimensions draw on two commonly used approaches to conceptualising environments: (1) as a source of information and (2) as a stock of resources. Dynamism also indicates uncertainty that erodes the ability of managers to predict future events and their impact on the organisation (Lumpkin \& Dess, 2001).

Regarding the measurement of market orientation, two perspectives have been widely accepted. The first, developed by Narver \& Slater (1990), argued that a market orientation "is the organisation culture that most effectively and efficiently creates the necessary behaviours for the creation of superior value for buyers, and, this, maintains superior performance for the business" (Mansouri et al., 2021). Market orientation is defined as a culture that creates essential company behaviours in effective and efficient ways to create superior value for buyers (Ozkaya et al., 2015). This study used the term market orientation to refer to implementing the marketing concept. Results showed that marketing orientation is an antecedent to create superior customer value, increase competitive capacities, and enhance financial performance (Ho et al., 2017). Therefore, a market-oriented organisation is one with activities consistent with the marketing concept.

Research on innovation has identified many human, social and cultural factors that are crucial for the effective operation of innovation at the company level. These factors are primarily learning-based. A technologically novel product has technological features or desired applications that significantly differ from the previous ones (Ko et al., 2020). These innovations are based on combining the available technologies in novel uses, can involve radically new technologies, and may result from applying current knowledge (Varadarajan, 2018). Technological procedure innovation means to adopt technologically novel or remarkably modified production techniques. The techniques can include modifications on the equipment, manufacturing organisation, or a combination of the modifications, and their derivation may be the application of novel knowledge (Oslo, 2005).

\section{The Conceptual and Theoretical Framework}

Innovation is assumed to be a vital factor in sustaining and building competitive advantage (Prajogo, 2014). Innovation is a mixture of knowledge and selection of appropriate resources to create value in a product or process or to improve them (Varadarajan, 2018). Regarding resource-based theory (RBT), an effective innovation results in better performance since innovation provides customers more value than what competitors provide and cannot be easily imitated. A study on Chinese companies showed that process and product innovations were correlated to each other significantly. However, recent literature does not provide detailed empirical results for the direction of this relationship (Gunday et al., 2011). Still, some indirectly related recent findings may exist. To better consider the customers' requirements and wishes, different forms of innovation can be employed, and this work addresses two main types of innovation, including product innovation and process innovation. Innovation influences the ability of market orientation by understanding customers, which increases production efficiency and improves the rate of sales and profitability. A strong MO with no commensurate development of strong innovation and technological capabilities may negatively affect novel product and market performance (Slater et al., 2010). Innovation practice plays a role in developing the economy via increasing the development of new markets and improving the existing markets. Strategic behaviour leads an organisation to align with its environment and forms its strategic characteristics and competencies. In addition, various MS attributes must be used for distinct innovative types. The effect of process innovation on product innovation should provide more resources through increased production efficiency (Lee et al., 2017). Hence, the following hypotheses were suggested: 
$\boldsymbol{H}_{1 a}$ : By creating innovation in the way of production, we can help to improve the company's performance results. $\boldsymbol{H}_{1 b}$ : By creating innovation in the production process, we can help to improve the company's performance results. $\boldsymbol{H}_{1 c}$ : Product innovation can be achieved by creating process innovation.

$\boldsymbol{H}_{1 d:}$ process innovation has a positive relationship with a company's market orientation.

$\boldsymbol{H}_{2 a}$ : product innovation significantly affects company performance.

$\boldsymbol{H}_{2 b}$ : product innovation has a positive relationship with a company's market orientation.

$\boldsymbol{H}_{2 c}$ : product innovation has a relationship with a company's marketing strategy.

Competitors, customer demands, and market mandates are external environmental factors, and companies choose their business strategies according to these factors (Lee et al., 2015). MS studies indicated that MO provides a company with market-sensing and customer-linking abilities, which result in better organisational performance. Business strategy deciding requires organisational planning, and market information and surveys are commonly used to identify business performance in a competitive market. Besides, external environmental business knowledge may affect the implementation of a business strategy executed by a company. Li and Zhou (2010) found that companies must employ market-oriented strategies to create a differentiation or cost advantage. Therefore, the following hypotheses were proposed:

$\boldsymbol{H}_{3 a}$ : Market orientation directly affects the type of selection and performance of the marketing strategy.

Market orientation leads to profitability. Based on the definition, with the help of market orientation, companies can identify and address the needs of the business environment (Mansouri et al., 2021). Therefore, companies require market-oriented approaches to create a competitive advantage (Jaworski \& Kohli, 1993). It should be kept in mind that companies are affected by all events in the business environment, and, therefore, their procedures and policies affect their business performance. In addition, Lee et al. (2015) stated that MO positively affects a company's business performance by increasing employee commitment. Hence, this hypothesis was raised:

$\boldsymbol{H}_{3 b}$ : market orientation positively affects the company performance.

Literature verifies the influence of competitive advantage on a company's performance since competitive advantage can cause the company to outperform its competitors (Porter, 1985). Results showed that low cost and technical capabilities affected its performance regardless of its entry time into the market (Lee et al., 2015). In addition, Lee et al. (2015) found that rare resources and capabilities and the utilisation of valuable materials contribute to a company's competitive advantage. It, in turn, increases its performance. Hence, this hypothesis was suggested:

$\boldsymbol{H}_{4}:$ MS positively affects performance.

Dynamic environments also allow companies to innovate in the process. Product innovations generally need process innovations since companies have to respond to changing demands of a dynamic environment and develop new products. They have to apply novel methods and technologies (DAIM, 2013). For example, developing new products needs innovation in process technologies and production and product supplying products in new ways to meet emerging markets. Marketing improves customer satisfaction and performance (Mansouri et al., 2021). In dynamic environments, companies have to use innovative strategies to improve their business performance and increase their profitability. Also, such environments force companies to innovate more effectively than if they were in environments with low dynamism (Prajogo, 2014). Therefore, we hypothesised:

$H_{5 a}$ : ED has a moderating role in the relationship between process innovation and company performance.

Distinguishing between the rate and unpredictability of environmental changes is of high importance. Dynamism should be restricted because it becomes unpredictable and increases the uncertainty of critical organisational members. It has been stated that the business environment is a contingency factor in strategic management studies in revealing the efficiency of strategies. For example, Miller (1988) suggested that differentiation strategies were suitable for dynamic environments while cost leadership strategies were better for stable environments. Literature showed that highly dynamic environments increased innovations (Lee, 2011). Companies have to invest in innovation due to fast technological changes and knowledge diffusion. They have to strengthen their competitive position to gain more market share and profitability. Hence, companies have to produce higher quality products to improve their business performance in more dynamic environments. Because customer preferences rapidly change in this kind of environment, companies need to address new market needs by offering product innovations capable of winning higher market share (Prajogo, 2014). Accordingly, the following hypothesis suggested:

$\boldsymbol{H}_{5 b}$ : ED has a moderating role in the relationship between product innovation and business performance.

MO is considered an attribute of an organisation, which describes the priority or preference placed on market information processing activities and their uses in the strategic processes. Instability in the environment causes uncertainty, which acts as a barrier to access the information required for identifying and understanding the cause and effect relations (Lee, 2011). Changes in the structure of the industry, the stability of market demands and the probability of an environmental shock are significant components that create uncertainties. In a dynamic 
environment, a market orientation that receives and processes market information can affect the performance of the company. Thus, this hypothesis was proposed:

$\boldsymbol{H}_{5 c}$ : $E D$ has a moderating role in the relationship between $M O$ and firm performance.

The context or environment of a company is "the totality of physical and social factors that are taken directly into consideration in the decision-making behaviour of individuals in the organisation"(D. yuan Li \& Liu, 2014). When the environment is relatively stable with little customer preference change or no significant technological progress, market orientation, MS, and competitive advantage are not significant. In addition, the relation between a dynamic environment and competitive advantage can be weaker or even negative. While in a strongly unstable context with opportunities and threats passing rapidly through competitors that are always around, this environmental instability decreases competitive position, making enterprises perform many intricate changes. Therefore, a dynamic environment can play a more important role. In a hyper-competitive environment with scarce sources, the only way for companies to get a series of short-term advantages is efficient sensing, making on-time necessary adjustments and implementing dynamically with environmental change. On the contrary, where resources are easy to get in less fierce environments, firms can implement former strategies and deploy resources freely to match environmental change; therefore, long-term competitive advantages can be gained in environments with relatively weak dynamics. When innovations urge competitors to retaliate, the result is a still more dynamic and unpredictable environment and the need for further change to maintain effective differentiation. If target markets are very heterogeneous, a company with focused products and methods might have to spread itself too thin and pursue many inappropriate customers in the wrong ways. Companies may therefore have to seek out a homogeneous environment to maximise their returns (Miller, 1988). Accordingly, we have suggested the following hypothesis:

$H_{5 d}$ : ED positively moderates the relationship between MS and company performance.

Figure 1 illustrates the conceptual framework of the research.

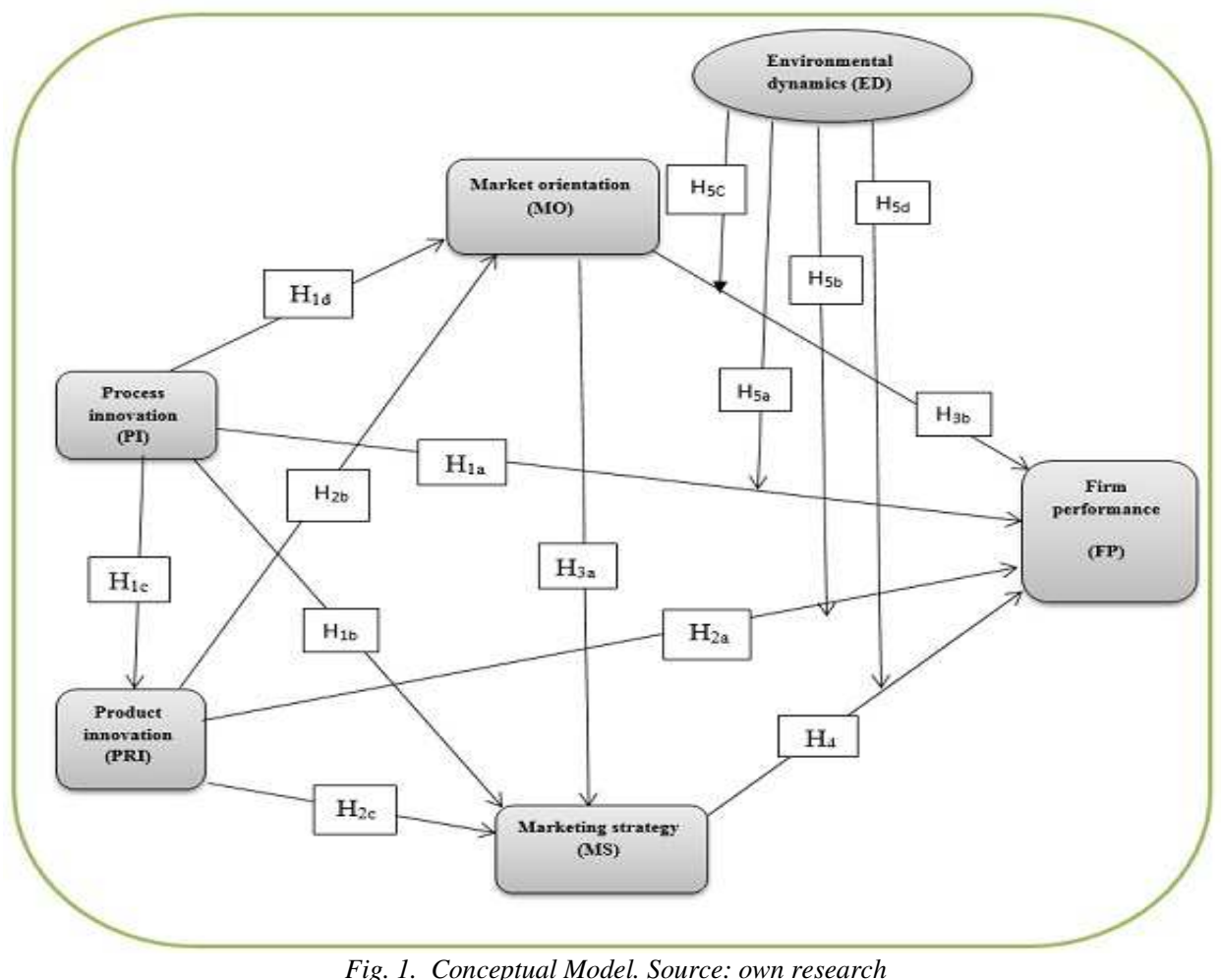

\section{Research Objective, Methodology and Data}

This research is categorised as descriptive, correlational and applied in nature. The sample consisted of the staff of 19 cement factories with a total of 1200 employees, from which 291 people, including top managers, vice president and advisors, were randomly selected using the Morgan sampling table. The following employees were excluded; 1) those who did not answer the questions and or did not answer the questions correctly. Finally, 291 samples were studied. The validity and reliability of the questionnaire were confirmed using SPSS. For MO and ED questions, 5-point scoring format ( $1=$ strongly disagree to $5=$ strongly agree) and for innovation, MS and company performance questionnaires 5-point scoring format (from $1=$ very high to 5 =very low) were employed. Sample characteristics are shown in Table 1. In addition, Table 2 shows the list of selected companies. 
Table 1. Demographic characteristics

\begin{tabular}{lcc}
\hline \multicolumn{3}{c}{ Table 1. Demographic characteristics } \\
\hline Gender & Frequency & \% \\
Male & 216 & 95.2 \\
Female & 11 & 4.8 \\
Age & & \\
$25-30$ & 62 & 27.3 \\
$31-40$ & 128 & 56.4 \\
$41-50$ & 31 & 13.7 \\
51 or more & 6 & 2.6 \\
Education level & & \\
Diploma & 1 & 0.4 \\
Associate Degree & 20 & 8.8 \\
Bachelor & 141 & 62.1 \\
Master & 64 & 28.2 \\
Ph.D. & 1 & 0.4 \\
Work Experience & & \\
1-5 & 37 & 16.3 \\
$6-10$ & 82 & 36.1 \\
$11-15$ & 78 & 34.4 \\
16-20 & 24 & 10.6 \\
More than 20 & 6 & 2.6 \\
\hline
\end{tabular}

Tab. 2. List of companies, number of employees and managers

\begin{tabular}{|c|c|c|}
\hline Name of company & Number of employees & Number of samples \\
\hline Abadeh & 106 & 26 \\
\hline Abiek & 94 & 23 \\
\hline Ekbatan & 55 & 13 \\
\hline Urmia & 35 & 8 \\
\hline Esfahan & 102 & 25 \\
\hline Estahban & 58 & 14 \\
\hline Ardabil & 40 & 10 \\
\hline Ilam & 45 & 11 \\
\hline Shargh & 46 & 11 \\
\hline Behbahan & 45 & 11 \\
\hline Bojnourd & 45 & 11 \\
\hline Bushehr & 120 & 29 \\
\hline Zanjan & 35 & 8 \\
\hline Sepahan & 95 & 23 \\
\hline Tehran & 75 & 18 \\
\hline Urmia White & 35 & 8 \\
\hline Khazar & 42 & 10 \\
\hline Khuzestan & 87 & 21 \\
\hline Sofian-Tabriz & 40 & 10 \\
\hline Total & 1200 & 291 \\
\hline
\end{tabular}

Table 3 also presents confirmatory factor analysis for variables with composite reliability (CR) and average variance extracted (AVE) with an acceptable level. AVE values further supported convergent validity, as they were close or more than 0.5 (Fornell \& Larcker, 1981). The obtained results revealed that the value of Cronbach's alpha passed the cut-off point of 0.7 for the proposed model.

Tab. 3. Factor analysis

\begin{tabular}{|c|c|c|c|c|}
\hline Factors \& variables & Source & $\begin{array}{l}\text { Factor } \\
\text { loading }\end{array}$ & $\mathbf{C R}$ & AVE \\
\hline Firm performance (FP) & \multirow{6}{*}{$\begin{array}{l}\text { Lee et al. (2015) } \\
\text { Hersey \& Goldsmith } \\
(1981)\end{array}$} & & & \\
\hline Non-financial performance $($ Cronbach's alpha $=\mathbf{0 . 8 6 8})$ & & & 0.91 & 0.716 \\
\hline 1. To what extent has the capabilities of new products and services improved? & & 0.815 & & \\
\hline 2. How much employee satisfaction has increased? & & 0.885 & & \\
\hline 3. How much customer satisfaction has increased? & & 0.850 & & \\
\hline $\begin{array}{l}\text { 4. To what extent are the authorities in the process of improving your } \\
\text { performance? }\end{array}$ & & 0.833 & & \\
\hline
\end{tabular}




\begin{tabular}{|c|c|c|c|c|}
\hline Innovations & Gunday et al. (2011) & & & \\
\hline Process innovation $(\mathrm{PI})($ Cronbach's alpha $=\mathbf{0 . 8 2 5})$ & & & 0.871 & $\mathbf{0 . 5 3 7}$ \\
\hline $\begin{array}{l}\text { 1. Determining and eliminating non-value adding activities in delivery related } \\
\text { processes. }\end{array}$ & & 0.651 & & \\
\hline $\begin{array}{l}\text { 2. Increasing output quality in manufacturing processes, techniques, machinery } \\
\text { and software. }\end{array}$ & & 0.781 & & \\
\hline $\begin{array}{l}\text { 3. Decreasing variable cost components in manufacturing processes, techniques, } \\
\text { machinery and software. }\end{array}$ & Prajogo et al. (2014) & 0.693 & & \\
\hline $\begin{array}{l}\text { 4. Determining and eliminating non-value adding activities in production } \\
\text { processes. }\end{array}$ & & 0.816 & & \\
\hline 5. We improve the speed and efficiency of our production processes. & & 0.653 & & \\
\hline 6. We use advanced technologies in our production processes. & & 0.783 & & \\
\hline Product innovation(PRI) $($ Cronbach's alpha $=0.819)$ & & & 0.873 & 0.538 \\
\hline $\begin{array}{l}\text { 1. Developing new products with technical specifications and functionalities } \\
\text { totally differing from the current ones. }\end{array}$ & & 0.877 & & \\
\hline $\begin{array}{l}\text { 2. Developing newness for current products leading to improved ease of use for } \\
\text { customers and to improved customer satisfaction. }\end{array}$ & & 0.575 & & \\
\hline $\begin{array}{l}\text { 3. Decreasing manufacturing costs in components and materials of current } \\
\text { products. }\end{array}$ & & 0.783 & & \\
\hline $\begin{array}{l}\text { 4. Increasing manufacturing quality in components and materials of current } \\
\text { products. }\end{array}$ & & 0.745 & & \\
\hline 5. We develop or use new technologies in our products. & & 0.839 & & \\
\hline 6. We develop or use new product features. & & 0.505 & & \\
\hline Marketing strategy $($ MS $)($ Cronbach's alpha $=\mathbf{0 . 8 3 9})$ & Porter (1989) & & 0.881 & 0.555 \\
\hline \multicolumn{5}{|l|}{ Differential strategy } \\
\hline 1. Our new products and service development offer superior benefits to customers. & & 0.758 & & \\
\hline $\begin{array}{l}\text { 2. We successfully differentiate ourselves from others through effective } \\
\text { advertising and promotion campaigns. }\end{array}$ & & 0.756 & & \\
\hline 3. The firm has prioritised innovation in its services to increase its customer fealty. & & 0.758 & & \\
\hline Cost strategy & Lee et al. (2015) & & & \\
\hline 4. Manufacturing costs are lower than our competitors. & & 0.806 & & \\
\hline $\begin{array}{l}\text { 5. The factory focuses on innovation with a view to presenting consumers with } \\
\text { the lowest prices. }\end{array}$ & & 0.807 & & \\
\hline $\begin{array}{l}\text { 6. The factory in order to minimise the possibility of entry of new competitors, } \\
\text { innovation in service provision tends above. }\end{array}$ & & 0.554 & & \\
\hline Marketing orientation(MO) (Cronbach's alpha = 0.817) & Prajogo (2014) & & 0.868 & 0.529 \\
\hline \multicolumn{5}{|l|}{ Intelligence generation } \\
\hline 1. We understand customers' demands for our products and services. & & 0.888 & & \\
\hline $\begin{array}{l}\text { 2. We periodically examine how recent changes in our operation affect our } \\
\text { customers. }\end{array}$ & & 0.531 & & \\
\hline \multicolumn{5}{|l|}{ Intelligence dissemination } \\
\hline $\begin{array}{l}\text { 3. Our marketing manager and directors from other departments continuously } \\
\text { discuss customers' demands. }\end{array}$ & & 0.723 & & \\
\hline 4. All members of our firm share important information about our competitors. & & 0.700 & & \\
\hline \multicolumn{5}{|l|}{ Integrated response } \\
\hline $\begin{array}{l}\text { 5. Our teams work together to improve our products and services by focusing on } \\
\text { our customers' demands. }\end{array}$ & & 0.685 & & \\
\hline 6. We do not neglect our customers' feedback on our products and services. & & 0.790 & & \\
\hline \multicolumn{5}{|l|}{ Environmental Dynamics(ED) $($ Cronbach's alpha = 0.889) } \\
\hline 1. Growth opportunities in this environment are high. & Miller (1988) & 0.734 & & \\
\hline 2. Changes in production technology and services are high. & & 0.591 & & \\
\hline 3. Product or service in our industry updates quickly. & & 0.830 & & \\
\hline 4. The acts of competitors are difficult to predict. & Liu et al.(2014) & 0.736 & & \\
\hline 5. In a year, our market has changed significantly. & & 0.609 & & \\
\hline 6. Our clients regularly ask for new products and services. & Prajogo (2014) & 0.717 & & \\
\hline 7. The technology in our industry progresses quickly. & & 0.818 & & \\
\hline $\begin{array}{l}\text { 8. In our market, the volumes of products and services to be delivered change fast } \\
\text { and often. }\end{array}$ & & 0.853 & & \\
\hline 9. In this environment, there are many research and development activities. & & 0.655 & & \\
\hline
\end{tabular}


Tab. 4. Discriminant validity

\begin{tabular}{llllll}
\hline & $\mathbf{1}$ & $\mathbf{2}$ & $\mathbf{3}$ & & \\
\hline & 0.745 & & & \\
1-Marketing strategy & 0.693 & 0.728 & 0.846 & \\
2-Market orientation & 0.685 & 0.695 & 0.622 & 0.733 \\
3-Firm performance & 0.699 & 0.715 & 0.651 & 0.421 \\
4-Process innovation & 0.518 & 0.706 & 0.733 & \\
5-Product innovation & & & \\
\hline
\end{tabular}

Note: Diagonals refer to the square root of the AVE, whereas the other matrix entries show correlations.

\section{Results and Discussion}

All hypotheses were tested by examining their statistical significance, sizes, and signs of path coefficients $(\beta)$ using the bootstrapping function of Smart PLS software version 3.0. To test our hypotheses, we used path coefficients R2 and t-value. Furthermore, different coefficient significances were reached for various $t$-values $(p$ $<0.1$ for $t>1.64 ; p<0.05$ for $t>1.96$; and $p<0.01$ for $t>2.56$ ). The $t$-values were strong and in the standard range for all variables. Table 5 reports the respective $t$-values and the assessed $p$-values.

Tab. 5. Outputs of the PLS analyses

\begin{tabular}{|c|c|c|c|c|c|}
\hline Hypotheses & Relationships & $\beta$ & t-values & $p$ & Confirmed \\
\hline $\mathrm{H}_{1 \mathrm{a}}$ & $\mathrm{PI} \rightarrow \mathrm{FP}$ & 0.471 & 5.771 & $<0.001$ & Confirmed \\
\hline $\mathbf{H}_{1 \mathrm{~b}}$ & $\mathrm{PI} \rightarrow \mathrm{MS}$ & 0.732 & 14.511 & $<0.001$ & Confirmed \\
\hline $\mathbf{H}_{1 \mathrm{c}}$ & $\mathrm{PI} \rightarrow \mathrm{PRI}$ & 0.864 & 61.895 & $<0.001$ & Confirmed \\
\hline $\mathbf{H}_{1 \mathrm{~d}}$ & $\mathrm{PI} \rightarrow \mathrm{MO}$ & 0.155 & 2.821 & $<0.01$ & Confirmed \\
\hline $\mathbf{H}_{2 \mathbf{a}}$ & $\mathrm{PRI} \rightarrow \mathrm{FP}$ & 0.326 & 4.617 & $<0.001$ & Confirmed \\
\hline $\mathbf{H}_{2 \mathrm{~b}}$ & $\mathrm{PRI} \rightarrow \mathrm{MO}$ & 0.779 & 14.905 & $<0.01$ & Confirmed \\
\hline $\mathbf{H}_{2 \mathrm{c}}$ & $\mathrm{PRI} \rightarrow \mathrm{MS}$ & -0.270 & 4.201 & $<0.001$ & Confirmed \\
\hline $\mathbf{H}_{3 \mathbf{a}}$ & $\mathrm{MO} \rightarrow \mathrm{MS}$ & 0.478 & 8.119 & $<0.001$ & Confirmed \\
\hline $\mathbf{H}_{3 \mathbf{b}}$ & $\mathrm{MO} \rightarrow \mathrm{FP}$ & 0.414 & 6.192 & $<0.001$ & Confirmed \\
\hline $\mathbf{H}_{4}$ & $\mathrm{MS} \rightarrow \mathrm{FP}$ & -0.272 & 3.226 & $<0.01$ & Confirmed \\
\hline $\mathbf{H}_{5 \mathrm{a}}$ & ED moderated between $\mathrm{PI} \rightarrow \mathrm{FP}$ & -0.183 & 2.465 & $<0.05$ & Confirmed \\
\hline $\mathbf{H}_{5 \mathrm{~b}}$ & ED moderated between $\mathrm{PRI} \rightarrow \mathrm{FP}$ & 0.277 & 2.05 & $<0.05$ & Confirmed \\
\hline $\mathbf{H}_{5 \mathrm{c}}$ & ED moderated between $\mathrm{MO} \rightarrow \mathrm{FP}$ & 0.084 & 1.372 & - & Not confirmed \\
\hline $\mathbf{H}_{5 \mathrm{~d}}$ & ED moderated between $\mathrm{MS} \rightarrow \mathrm{FP}$ & -0.084 & 1.298 & - & Not confirmed \\
\hline
\end{tabular}

Index $\mathbf{R}^{2}$. The percentage of the variation of a construct is measured by $\mathrm{R}^{2}$, which is the statistical measure of the per cent of the variance in a data set. In general, higher $R^{2}$ means higher variance (Chen et al., 2012). The values obtained for product innovation, marketing strategy, market orientation, and company performance without a moderate variable were $0.774,0.839,0.841$, and 0.885 , respectively, and despite the variable of the coefficients of determination, index F2 for product innovation was 0.747 , MS was 0.839 , market orientation was 0.841 , and the performance of the company was 0.906 .

GOF index. Wetzels et al. (2009) classified effective size into three groups large (0.36), medium (0.25), and small (0.1). The following equation (1) was used to calculate the GOF indicator:

$$
\mathrm{GOF}=\sqrt{\operatorname{avrage}(\text { Comunalitie }) * \operatorname{average}\left(R^{2}\right)}=0.68
$$

The obtained value (0.68) passed the cut-off value assigned for a large effective size of $\mathrm{R}^{2}(0.36)$ and allowed us to conclude that the proposed model performed well.

F2 index. The significance factor related to the moderator variable of ED between process innovation and the performance of the company was 2.465 , and significance coefficients related to the moderation of environmental dynamic between product innovation and the company performance was 2.05 , which were more than 1.96 at $95 \%$ confidence level; therefore, it was verified that ED moderated the relationships between process and product innovations and company performance. After recognizing that the moderator variable could moderate the relationship between the two endogenous and exogenous variables, the severity of the moderator variable's effect was determined. In fact, after the significance of the T-value in the researcher's confidence level was confirmed, the moderation power of this variable had to be also calculated. Using the following equation, we calculated the effect of the variable's modulation. Weak, moderate, and strong effects are represented by values of $0.02,0.15$, and 0.35 , respectively.

$$
\mathrm{F} 2=\frac{R_{\text {model with moderator }(1)}^{2}-R_{\text {model without moderator }}^{2}}{1-R_{\text {model with moderator }(1)}^{2}} .
$$


The resulting value was 0.59 , which indicated a strong moderation effect.

Hypotheses $\mathrm{H}_{1 \mathrm{a}}$ and $\mathrm{H}_{1 \mathrm{~b}}$ posited that process innovation positively affects the company performance and marketing strategy. As shown in Table 5, the influences of process innovation $(\beta=0.471, t=5.771, p<0.001)$ on product innovation and performance $(\beta=0.326, t=4.617, p<0.001)$ were confirmed. In $\mathrm{H}_{1 \mathrm{a}}$, the results indicated that the company could better respond to its environmental changes through its process innovation and achieve new capabilities such as reducing the cost of producing, delivering each unit, increasing quality and production, delivering new products, and improving the existing products, to improve its performance. Rangus \& Slavec (2017) showed that innovation positively affects company performance. As Prajogo et al. (2014) stated, innovation in the process provides an alternative path of production for companies in very competitive contexts because it saves cost and may not be readily copied by competitors. Hence, companies are more probably to introduce process innovation in very competitive contexts. Liao (2016) indicated that process innovation positively affects marketing strategy. In $\mathrm{H}_{1 \mathrm{~b}}$, as Prajogo et al. (2014) stated, product innovation provides customers with different amounts of novelty and quality. Increasing product quality and producing new products increase customer satisfaction, meet market requirements and improve sales, and as companies perform better, more improved features, like integrated facilities than similar products by competitors, are provided. Another competitive advantage of product innovation is that customers observe the values that can guide them in buying decisions. Varadarajan (2018) specified that innovation is a combination of knowledge and selection of appropriate resources to create value in a product or process or improve them, which in turn improves the performance of the company.

The influences of process innovation on product innovation $(\beta=0.864, t=61.895, p<0.001)$ and on $\mathrm{MO}(\beta$ $=0.155, t=2.821, p<0.01$ ) were significant. Therefore, $\mathrm{H}_{1 \mathrm{c}}$ and $\mathrm{H}_{1 \mathrm{~d}}$ were supported. $\mathrm{In}_{\mathrm{H}} \mathrm{H}_{1 \mathrm{c}}$, innovation results in changes in the organisation and its market offerings and is a weapon that marketing strategists use to create a sustainable competitive advantage to overcome customers and markets. The assets and competencies of the organisation, along with innovation in processes, provide new and different market offers, which, when successful on the market, bring a lot of value to the company. According to $\mathrm{H}_{1 \mathrm{~d}}$, research has shown that marketing costs are high for innovators. The quality of the provided service is closely related to product quality understanding, and therefore product innovation improves the understanding of the quality of product and helps the company's business. That is why product innovation has a negative impact on marketing strategy because innovating the product's increasing market orientation does not require high costs for marketing strategies.

$\mathrm{H}_{2 \mathrm{a}}$ showed that process innovation significantly and positively affects the company performance $(\beta=0.864$, $t=61.895, p<0.001)$. Rangus \& Slavec (2017) showed that innovation positively affects company performance. Gunday et al. (2011) concluded that innovation in processes was necessary to track product innovations, which meant that process improvement was effective in successful product/service innovation. Hence, innovative solutions that increase the numbers of production stages and new and higher benefits, including higher qualities, values, speed and lower costs of production, may enhance the likelihood of products, materials, technical features, capabilities, and so forth for meeting the customer's needs.

$\mathrm{H}_{2 \mathrm{~b}}$ and $\mathrm{H}_{2 \mathrm{c}}$ showed the effect of products innovations on market orientation $(\beta=0.155, t=2.821, p<0.01)$ and on MS $(\beta=0.779, t=14.905, p<0.001)$. Hence, $\mathrm{H}_{2 \mathrm{~b}}$ and $\mathrm{H}_{2 \mathrm{c}}$ were supported. $\mathrm{In}_{2 \mathrm{~b}}$, by investigating the effect of process innovation on gaining market orientation, we emphasised the importance of process innovation to managers. The results showed that process innovation reduced production costs, increased production quality, produced new products, changed the customer's criteria towards the products, and increased their tendency to the company's products, which also positively affected the MO. Then, the company positively affected MO by creating process innovation. $\mathrm{H}_{2 \mathrm{c}}$ showed that creating innovation in the process leads to the production of new products. Product innovations that address the needs of the market or improve the quality of products will tend to lead customers to novel or improved products that orient the market towards these goods. Therefore, it was concluded that product innovation positively and significantly affected market orientation. Ho et al. (2017) illustrated that innovation is very important in competitive markets, so leading companies in the market create knowledge by using knowledge and recognizing the needs of the market and the customer.

For $\mathrm{H}_{3 \mathrm{a}}$, the result showed that MO significantly and positively affects the MS $(\beta=0.478, t=8.119, p<$ 0.001). As product and process innovation increase the willingness of customers to the company products, this also increases the market orientation of the product. On the other hand, innovation in process and product will be more successful with the correct use of marketing strategy. As a result, MO positively influences the use of marketing strategy. As Lee et al. (2015) stated, market orientation facilitates the MS of companies, which positively affect their business performance. MO, marketing strategies, differentiation, and cost leadership. Thus, it is expected that market orientation positively affects the strategy of differentiation and cost leadership strategies.

$\mathrm{H}_{3 b}$ proposed the positive effect of MO on company performance. It was found that the influence of MO on performance $(\beta=0.414, t=6.192, \mathrm{p}<0.001)$ was positive and significant. Therefore, $\mathrm{H}_{3 \mathrm{~b}}$ was supported. Regarding the results and for showing the positive impact of product and process innovations on market orientation, there was a market satisfaction of the product, increasing customer satisfaction and nonfinancial function of the company. Taherdangkoo et al. (2019) evaluated industry improvements to identify customer needs, and selecting 
and positioning the appropriate marketing strategy leads to better results. Lee et al. (2015) observed a relationship between MO and the nonfinancial function of a company. MO is an essential crucial tool in achieving the competitive advantage of satisfaction. In this way, using a market orientation, a model was developed to grow the business and sustainability of the company's performance. Ho et al. (2017) discussed that leading companies in the market use the knowledge and identify the needs of the market and the customer to create innovation, which will improve performance.

The influence of MS on company performance $(\beta=-0.272, t=3.226, p<0.01)$ was significant as predicted. Therefore, $\mathrm{H}_{4}$ was supported. For a company to be able to adapt properly to different markets, MS must take into account internal and external business environments that affect company performance. From the studies, it can be seen that if competitors can easily imitate a competitive advantage, it will not survive and will disappear over time. On the other hand, any strategy the company chooses brings risks. Companies that follow cost leadership strategies invest considerably in fixed assets to achieve high profits. This enhances the operating leverage of the company. Further, differentiation strategy may lead to the failure of producing new products in the market or to the ineffectiveness of research and development. In this research, cost leadership and differentiation strategies were measured, and because companies do not use both strategies at the same time, it showed a negative effect. Mansouri et al. (2021) stated that marketing improves customer satisfaction and performance. Lee et al. (2015) rejected the impact of cost leadership strategy but confirmed the impact of differentiation strategy.

The moderating effects of ED on process and product innovations were tested. The findings showed that ED weakens the relationship between process innovation and business performance $(\beta=-0.183, t=2.465, p<0.05)$ and relationship between product innovation and business performance $(\beta=0.277, t=2.05, p<0.05)$. Therefore, $\mathrm{H}_{5 \mathrm{a}}$ and $\mathrm{H}_{5 \mathrm{~b}}$ were supported. In $\mathrm{H}_{5 \mathrm{a}}$, the relationship between company performance and process innovation without moderator had a coefficient of 0.47 and a $t$-value of 5.77, but when ED was added as a moderating factor to the model, the path coefficient was 0.25 , and a $t$-value was 2.12 . This suggested that ED, with its negative role, reduced the impact of process innovation on performance. Characteristics of dynamic environments are modifications in technology, diversity in customer preferences, and fluctuation or instability in the product demands. Dynamic environments make available products and services obsolete and need novel and advanced facilities. Market changes require companies that are constantly seeking new knowledge and technology to meet customer demands and preferences. Process innovation in high-mobility environments is lower than that in low dynamic environments. The market is characterised by low technological dynamics and low customer demand, and as the impact of process innovation on company performance is higher and positive, moderation is due to ED in the community. It has been considered high, which has caused a negative adjustment. In $\mathrm{H}_{5 \mathrm{~b}}$, the relationship between product innovation and company performance without moderator variable has a path coefficient of 0.32 and $t$ value of 4.61, but when ED is added as a moderating factor to the model, the path coefficient becomes 0.29 , and a $t$-value becomes 3.19. This shows that ED, with its positive role, reduces the effect of product innovation on performance. Prajogo et al. (2014) showed that a dynamic environment highlights the positive impact of the product innovation on the company performance and the requirement for management to concentrate on the development of new products in dynamic contexts for filling the gaps between different sectors of the market. Ahmed et al. (2021) showed that the dynamics of the environment as an opportunity has a positive and significant effect on the type of selection of the company's competitive advantages.

However, the findings showed that ED did not have a moderating role in the relationship between MO and company performance $(\beta=-0.084, t=1.298, p>0.05)$ and that between marketing strategy and business performance $(\beta=0.084, t=1.372, p>0.05)$. Therefore, $\mathrm{H}_{5 \mathrm{c}}$ and $\mathrm{H}_{5 \mathrm{~d}}$ were not supported. The relationship between MO and company performance without moderator had a path coefficient of 0.41 and a $t$-value of 6.19. However, when ED was added as a moderating factor to the model, the coefficient of the path became 0.33 , and a $t$-value became 4, which suggested that ED had reduced the impact of orientation on performance.

It is better for managers to use process innovation in their products to increase company performance. In other words, if we accept that we die without innovation, and if the axis of innovative ideas is to be considered product innovation, then process innovation is also required. Therefore, the effect of innovative strategies on performance is a general issue because it is principally for performance. There is a great need for innovation. Managers are advised to try for improving the quality of the products or produce new products. New products refer to market performance from customer satisfaction, sales goals, and profitability of company products. In other words, new products determine how a company will enter the market through a systematic product development process for a series of products aimed at commercialisation.

When managers at their companies benefit from process innovations, they use MS to innovate and form a meeting with staff to select the type of MS. In order for innovation to be successful as a competitive advantage, the benefits of innovation must be exploited through appropriate competitive marketing strategies. When it comes to product innovation in a company, it is best not to use appropriate MS or use marketing strategy as much as possible. It can be concluded that, for optimal performance and the creation of competitive advantages for the survival and sustainability of an organisation in a competitive environment, different aspects of product innovation, process innovation and competitive marketing strategies should be considered for innovation. It is advisable for process 
innovation managers to focus on product innovation that includes increasing the quality of existing products or producing novel products. Product-process coordination contributes mainly to improving performance, and if any product or process innovation is not consistent with the other - even if it fits within the framework of rival values, it improves the product's performance. In addition to being consistent with the value framework of competitors, there must also be internal coordination between product and process innovation. Better-coordinated industries have demonstrated better performance. In other words, industries that align their process innovations with product innovations have achieved better performance in terms of key performance indicators in organisational evaluations.

According to the relationship between process innovation and MO, it is suggested that company managers improve their equipment, reduce the production costs, increase the quality of the products, and produce new products to satisfy customers and supply market needs. Product innovation is more likely to attract more customers and their satisfaction, which affect market orientation. In the marketplace, customer satisfaction forms the core of company activities, and all the company activities should be in line with the needs of customers. In this regard, manufacturers are trying to establish a link between their products and customers' requirements and try to produce goods to meet their needs and align with their demands. As a result, product innovation can be one of these tools. Managers need to identify the market orientation and determine their MS accordingly. To make a company more competitive than its competitors, it needs to develop competitive business strategies for operation and marketing. This could be achieved by developing good conditions, new services, effective communication, high-quality products, rapid and safe delivery and logistics, and competitive prices. Managers are encouraged to emphasise the MO more because market orientation brings a competitive advantage that positively affects company performance. The process that a company committed to becoming a marketplace can remain competitive and constructive in business is to identify the market orientation and advance a competitive advantage.

In accordance with external and internal conditions of the company and based on the innovation used in the processes and products, it is better managers select the MS with a positive impact on company performance; and provide employees with adequate information about the MS used. The results will form the basis of numerous meetings and their opinions. The analysis in this study states that the current and future performances of the firms will change with regard to the type of strategy they are going to take. Considering the role and importance of the type of strategy to meet the company's goals and how to achieve these goals, corporate finance executives can significantly impact company performance by adopting the decisions they make. Some resources and processes are readily imitated. If managers invest in these resources, they can obtain short-term operational excellence. Nevertheless, this advantage may not be sustainable because competitors can easily mimic these resources. Of course, this does not mean that all companies benefit from a differentiation strategy. Managers should consider a balance.

\section{Conclusion}

The rapid pace of technological change is a major issue in recent business that makes planning and decisionmaking impossible without a proper understanding of the most advanced and future technologies. Companies under difficult and dynamic conditions need to identify the proper ED for the company, industry and each project. However, what percentage of each organisation is devoted to product and process development activities is another issue related to the organisations' existing and strategic positions in the demand market. Therefore, these companies need research activities, and it is important to consider development as one of the best ways to make innovative products. It is suggested that companies seek to coordinate process and product innovation strategies to overcome environmental changes. By conducting meetings to gain knowledge about customer opinions and how they handle their complaints, managers can take the direction of the market in favour of their company. Due to their high volatility and environmental changes in dynamic environments, it is better not to focus on market orientation to improve performance or on market orientation for competitive advantage. Employees need to be encouraged and aware of sales information and marketing strategies used to increase company performance based on ED and employee feedback from the marketing strategies they use.

\section{References}

Ahmed, R. R., \& Streimikiene, D. (2021). Environmental issues and strategic corporate social responsibility for organizational competitiveness. Journal of Competitiveness, 13(2), 5-22. https://doi.org/10.7441/JOC.2021.02.01

Chari, S., Balabanis, G., Robson, M. J., \& Slater, S. (2017). Alignments and misalignments of realized marketing strategies with administrative systems: Performance implications. Industrial Marketing Management, 63, 129-144. https://doi.org/10.1016/j.indmarman.2016.11.002

DAIM, T. U. (2013). Are Formal Technology Integration Processes Needed for Successful Product Innovations? 
International Journal of Innovation 1350016. https://doi.org/10.1142/S1363919613500163

Gunday, G., Ulusoy, G., Kilic, K., \& Alpkan, L. (2011). Effects of innovation types on firm performance. International Journal of Production $\quad$ Economics, $133(2), \quad 662-676$. https://doi.org/10.1016/j.ijpe.2011.05.014

Ho, K. L. P., Nguyen, C. N., Adhikari, R., Miles, M. P., \& Bonney, L. (2017). Exploring market orientation, innovation, and financial performance in agricultural value chains in emerging economies. Journal of Innovation \& Knowledge, 1-12. https://doi.org/10.1016/j.jik.2017.03.008

İpek, İ. (2021). The relevance of international marketing strategy to emerging-market exporting firms: from a systematic review towards a conceptual framework. In International Marketing Review (Vol. 38, Issue 2). https://doi.org/10.1108/IMR-02-2020-0017

Jaworski, B. J., \& Kohli, A. K. (1993). Market Orientation: Antecedents and Consequences. Journal of Marketing, 57(3), 53. https://doi.org/10.2307/1251854

Jintana, J., \& Mori, T. (2019). Customer Clustering for A New Method of Marketing Strategy Support wthin the Courier Business. 1-19.

Kirca, A. H., Jayachandran, S., \& Bearden, W. O. (2005). Market orientation: A meta-analytic review and assessment of its antecedents and impact on performance. Journal of Marketing, 69(2), $24-41$. https://doi.org/10.1509/jmkg.69.2.24.60761

Ko, W. W. (Joyce), Chen, C. H. S., Liu, G., Nguyen, B., \& Takeda, S. (2020). IT-based product innovation strategies for small firms. Information Technology and People, 33(6), 1489-1514. https://doi.org/10.1108/ITP-07-2018-0343

Lee, L. T.-S. (2011). The effects of environmental dynamism and team strain on product innovation: The moderating role of perceived diversity climate. African Journal of Business Management, 5(22), 87408752. https://doi.org/http://dx.doi.org/10.5897/AJBM10.1140

Lee, R., Lee, J.-H., \& Garrett, T. C. (2017). Synergy effects of innovation on firm performance. Journal of Business Research, August. https://doi.org/10.1016/j.jbusres.2017.08.032

Lee, Y. K., Kim, S. H., Seo, M. K., \& Hight, S. K. (2015). Market orientation and business performance: Evidence from franchising industry. International Journal of Hospitality Management, 44, $28-37$. https://doi.org/10.1016/j.ijhm.2014.09.008

Li, D. yuan, \& Liu, J. (2014). Dynamic capabilities, environmental dynamism, and competitive advantage: Evidence from China. Journal of Business Research, 67(1), 2793-2799. https://doi.org/10.1016/j.jbusres.2012.08.007

Li, J. J., \& Zhou, K. Z. (2010). How foreign firms achieve competitive advantage in the Chinese emerging economy: Managerial ties and market orientation. Journal of Business Research, 63(8), 856-862. https://doi.org/10.1016/j.jbusres.2009.06.011

Liao, Z. (2016). Temporal cognition, environmental innovation, and the competitive advantage of enterprises. Journal of Cleaner Production, 135, 1045-1053. https://doi.org/10.1016/j.jclepro.2016.07.021

Liu, W., \& Atuahene-gima, K. (2018). Enhancing product innovation performance in a dysfunctional competitive environment: The roles of competitive strategies and market-based assets is. Industrial Marketing Management, December 2017, 1-14. https://doi.org/10.1016/j.indmarman.2018.01.006

Lumpkin, G. T., \& Dess, G. G. (2001). Linking two dimensions of entrepreneurial orientation to firm performance: The moderating role of environment and industry life cycle. Journal of Business Venturing, 16(5), 429451. https://doi.org/10.1016/S0883-9026(00)00048-3

Mansouri, H., Sadeghi Boroujerdi, S., Polonsky, M., Husin, M. M., \& Seydi, M. (2021). Investigating the mediating role of market orientation between internal marketing and the development of entrepreneurial orientation within private sports clubs. New England Journal of Entrepreneurship, ahead-of-p(ahead-ofprint). https://doi.org/10.1108/neje-12-2020-0055

Miller, D. (1988). Relating Porter' S Business Strategies To Environment and Structure: Analysis and Performance Implications. 31(2), 280-308.

Naja, S., Naja, Z., Naudé, P., Oghazi, P., \& Zeynaloo, E. (2018). How collaborative innovation networks a ff ect new product performance : Product innovation capability, process innovation capability, and absorptive capacity. Industrial Marketing Management, February, $0-1$. https://doi.org/10.1016/j.indmarman.2018.02.009

Najafi-Tavani, S., Sharifi, H., \& Najafi-Tavani, Z. (2016). Market orientation, marketing capability, and new product performance: The moderating role of absorptive capacity. Journal of Business Research, 69(11), 5059-5064. https://doi.org/10.1016/j.jbusres.2016.04.080

Narver, J. C., \& Slater, S. F. (1990). The of Effect Market Orientation on Business Profitability. Journal of Marketing, 54(4), 20-35. https://doi.org/10.2307/1251757

Oslo. (2005). Oslo manual. 1-113. https://doi.org/10.1787/9789264013100-en

Ozkaya, H. E., Droge, C., Hult, G. T. M., Calantone, R., \& Ozkaya, E. (2015). Market orientation, knowledge 
competence, and innovation. International Journal of Research in Marketing, 32(3), 309-318. https://doi.org/10.1016/j.ijresmar.2014.10.004

Porter, M. E. (1985). Competitive Strategy: The Core Concepts. In Creating and Sustaining Competitive Advantage. https://doi.org/10.1007/978-3-319-54540-0

Prajogo, D. I. (2014). The strategic fit between innovation strategies and business environment in delivering business performance. International Journal of Production Economics. https://doi.org/10.1016/j.ijpe.2015.07.037

Rangus, K., \& Slavec, A. (2017). The interplay of decentralization, employee involvement and absorptive capacity on firms' innovation and business performance. Technological Forecasting and Social Change, 120, 195203. https://doi.org/10.1016/j.techfore.2016.12.017

Salunke, S., Weerawardena, J., \& Mccoll-kennedy, J. R. (2019). The central role of knowledge integration capability in service innovation- based competitive strategy. Industrial Marketing Management, 76(August 2018), 144-156. https://doi.org/10.1016/j.indmarman.2018.07.004

Slater, S. F., Mohr, J. J., \& Sengupta, S. (2010). Market Orientation. Wiley International Encyclopedia of Marketing, 1-8. https://doi.org/10.1002/9781444316568.wiem01031

Taherdangkoo, M., Mona, B., \& Ghasemi, K. (2019). The role of industries' environmental reputation and competitive intensity on sustainability marketing strategy: Customers' environmental concern approach. Spanish Journal of Marketing - ESIC, 23(1), 3-24. https://doi.org/10.1108/SJME-02-2018-0005

Varadarajan, R. (2018). Innovation, innovation strategy, and strategic innovation. Review of Marketing Research, 15, 143-166. https://doi.org/10.1108/S1548-643520180000015007

Wang, D., Su, Z., \& Guo, H. (2019). Top management team con fl ict and exploratory innovation: The mediating impact of market orientation. January. https://doi.org/10.1016/j.indmarman.2019.02.014

Wang, X., \& Bao, H. (2017). Alliance portfolios and firm performance: The moderating role of environmental dynamics. Industrial Management and Data Systems, 117(8), 1550-1566. https://doi.org/10.1108/IMDS09-2016-0351 